\title{
Scanning electron microscopy on Gotocotyla acanthura (Monogenea, Gotocotylidae) from Pomatomus saltatrix (Ostheichthyes, Pomatomidae) in Brazil
}

Microscopia eletrônica de varredura de Gotocotyla acanthura (Monogenea, Gotocotylidae) parasita de Pomatomus saltatrix (Ostheichthyes, Pomatomidae) no Brasil

Maria Clara Pamplona-Basilio할 Helene Santos Barbosa²; Simone Chinicz Cohen ${ }^{1 *}$

${ }^{1}$ Laboratório de Helmintos Parasitos de Peixes, Instituto Oswaldo Cruz - FIOCRUZ

${ }^{2}$ Laboratório de Biologia Estrutural, Instituto Oswaldo Cruz - FIOCRUZ

Received March 2, 2011

Accepted April 5, 2011

\begin{abstract}
Gotocotyla acanthura (Parona \& Perugia, 1896) Meserve, 1938 collected from the gills of Pomatomus saltatrix from the coast of the state of Rio de Janeiro state was analyzed using scanning electron microscopy (SEM). The study demonstrated the presence of a buccal cavity, a genital atrium on the ventral surface and a muscular structure on the dorsal surface at the level of the body constriction. An elongated haptor with 80 to 120 pedunculated clamps symmetrically distributed in two rows, with rib-like thickenings and a curved lappet bearing a pair of hooks at the posterior extremity of the body were also observed. The cirrus could be seen protruding from the genital atrium, armed with pectinate spines along its length and presenting up to eight pointed spines around the genital atrium.
\end{abstract}

Keywords: Monogenea, parasites, fishes, surface topography.

\section{Resumo}

Gotocotyla acanthura (Parona \& Perugia, 1896) Meserve, 1938, coletado das brânquias de Pomatomus saltatrix do litoral do Estado do Rio de Janeiro, foi estudado por microscopia eletrônica de varredura (MEV). O estudo demonstrou a presença de uma cavidade bucal, átrio genital na superfície ventral e uma estrutura muscular na superficie dorsal ao nível da constricçáo do corpo. $\mathrm{Na}$ extremidade posterior do corpo, foi observado o haptor alongado, apresentando 80 a 120 pinças pedunculadas, distribuídas em duas fileiras simétricas e uma porção terminal curvada provida de um par de ganchos. O cirro foi visualizado projetando-se do átrio genital, armado com espinhos pectinados ao longo do seu comprimento, apresentando até 8 espinhos pontiagudos ao redor do átrio.

Palavras-chave: Monogenea, parasitos, peixes, topografia da superfície.

In Brazil, monogeneans collected from Pomatomus saltatrix (Linnaeus) were described as Gotocotyla travassosi by Kohn et al. (1971). This species was then transferred, by Lebedev (1984), to the genus Swakopella, which is characterized by the presence of two lateral vaginae and an additional dorsal sucker. Hayward and Rohde (1999) examined the type material of G. travassosi and reported that the measurements of the copulatory organ and its spines in the original description were incorrect. Hayward and Rohde (1999) did not observe the lateral vaginae described by Lebedev (1984) and thus, synonymized G. travassosi with G. acanthura (Parona \& Perugia, 1896) Meserve, 1938, which

\footnotetext{
${ }^{*}$ Corresponding author: Simone Chinicz Cohen

Laboratório de Helmintos Parasitos de Peixes,

Instituto Oswaldo Cruz - FIOCRUZ, Av. Brasil 4365,

CEP 21045-900, Rio de Janeiro, RJ, Brasil

e-mail:scohen@ioc.fiocruz.br
}

was originally described from Brama brama (Bonnaterre) in Italy. Since then, this species has been reported in different species of scombrids and perches in the Atlantic, Indian and Pacific Oceans (RAMALINGAM, 1961; KORATHA, 1955; LEBEDEV; PARUKHIN, 1969; YOUNG, 1970; BRAVO-HOLLIS; CABALLERO-DELOYA, 1979; SHEN; QIU, 1995; WILLLIAMS; BUNKLEY-WILLIAMS, 1996).

Studies on species of Monogenea by means of scanning electron microscopy (SEM) have been used to supplement observations using light microscopy and have helped to provide information of great accuracy regarding species morphology. In the present paper, ultrastructural data obtained from SEM studies on specimens of $G$. acanthura collected from P. saltatrix were used to provide detail and extend the current knowledge of the morphology of this species. 
Monogeneans collected from the gills of Pomatomus saltatrix from the coast of the State of Rio de Janeiro, Brazil, were fixed under gentle cover glass pressure in 5\% formaldehyde. Some of the samples were stained with Langeron's alcoholic-acid carmine, dehydrated in an ethyl alcohol series, cleared in beechwood creosote and mounted in Canada balsam. The specimens were observed under a Zeiss Axioskop 2 Plus microscope and the images were captured using a SONY MPEGMovie EX DSC-S75
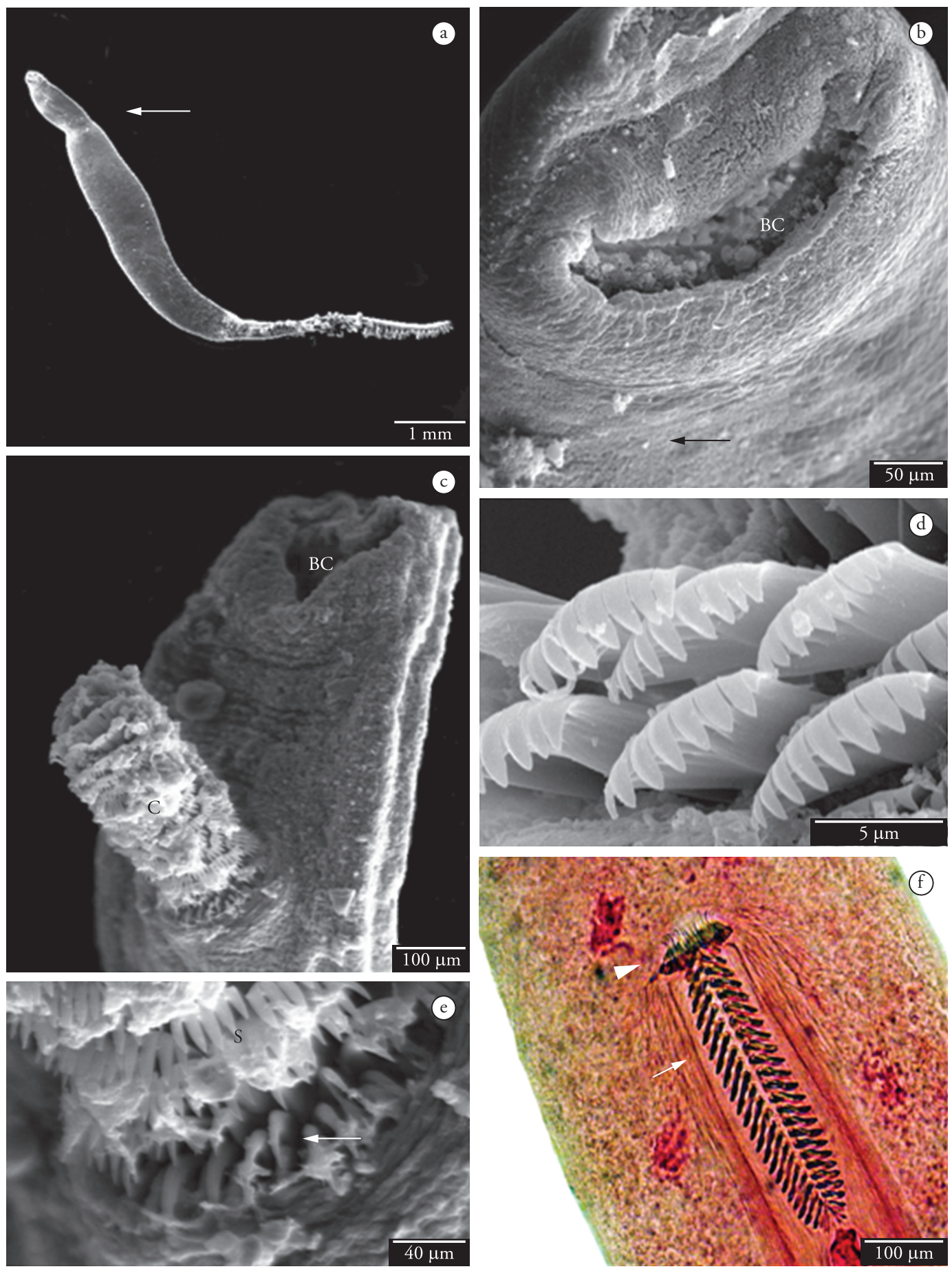

Figure 1. Gotocotyla acanthura. a) SEM (full view) showing the body constriction (arrow). Bar $=1 \mu \mathrm{m} . \mathrm{b})$ SEM showing anterior region with buccal cavity $(B C)$ and papillae (arrow). Bar $=50 \mu \mathrm{m}$. c) SEM showing detail of the anterior part of body, showing buccal cavity $(B C)$, genital atrium with cirrus everted $(C)$ and the transversal striations and ridges of the tegument (arrows). Bar $=100 \mu \mathrm{m}$. d) SEM showing cirrus with pectinate spines $(S)$. Bar $=5 \mu \mathrm{m}$. e) SEM showing the cirrus pectinate spines $(S)$ in detail and pointed spines at the base $($ arrow $)$. Bar $=40 \mu \mathrm{m}$. f) Light microscopy showing cirrus with pectinate spines along its length (thick white arrow) and pointed spines around the genital atrium (white arrow). Bar $=100 \mu \mathrm{m}$. 

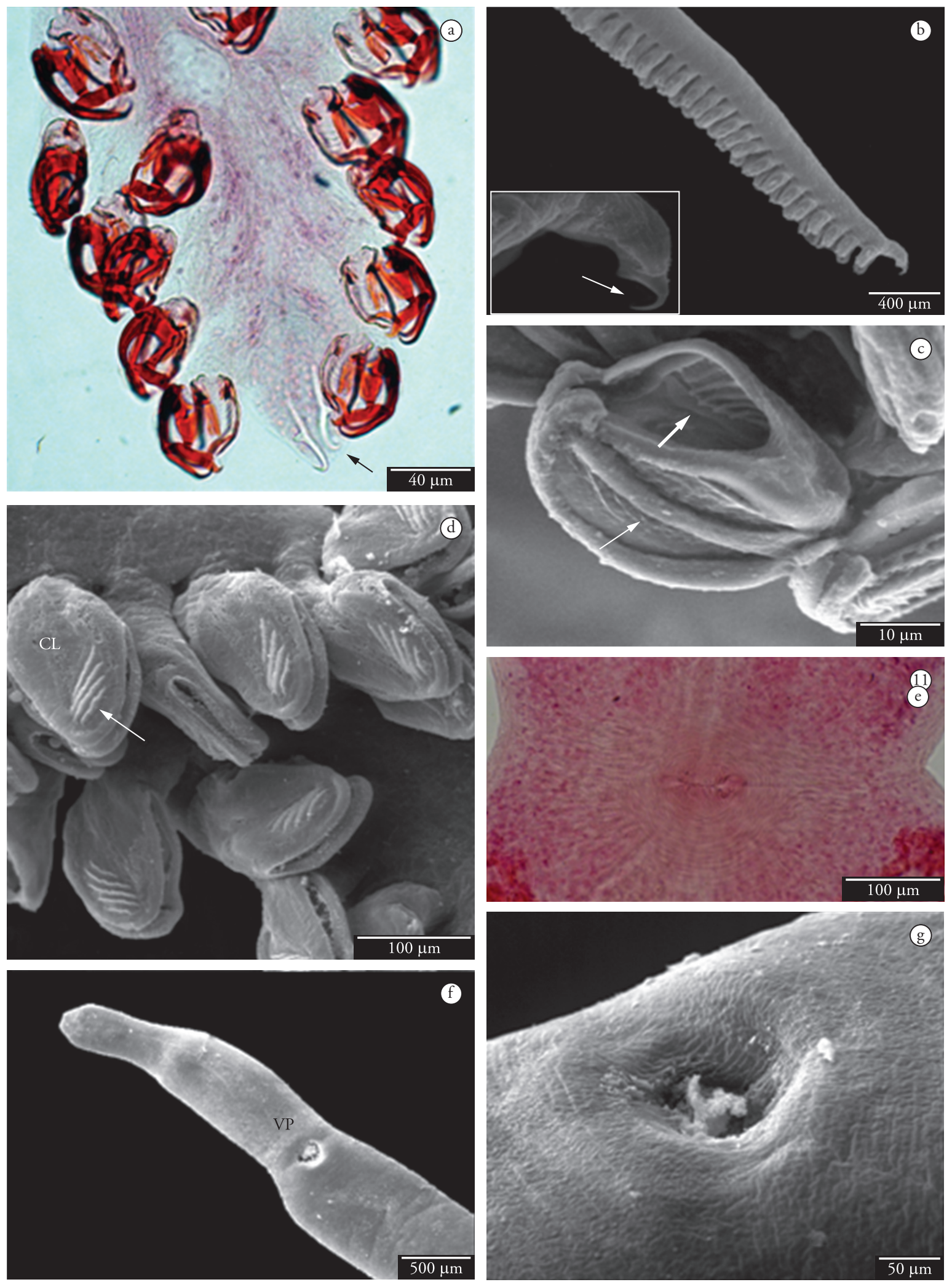

Figure 2. Gotocotyla acanthura. a) Light microscopy on lower part of the haptor showing two rows of clamps and a pair of hooks (arrow). Bar $=40 \mu \mathrm{m}$. b) SEM showing the haptor $(H)$ with clamps (arrow) and lappet $(L)$ at the extremity. Bar $=400 \mu \mathrm{m}$. inset: SEM with detail of posterior region of body with lappet (arrow). Bar $=100 \mu \mathrm{m} . \mathrm{c})$ SEM on a clamp showing the median sclerite (thin arrow) and the inner part of upper jaw with rib-like thickenings (thick arrow). Bar $=10 \mu \mathrm{m}$. d) SEM on the clamps $(C L)$ with threefold to fivefold thickening (arrow). Bar $=100 \mu \mathrm{m}$. e) Light microscopy on the vaginal structure. Note the strong musculature. Bar $=100 \mu \mathrm{m}$. f) SEM on the anterior region showing the vaginal pore $(V P)$. Bar $=500 \mu \mathrm{m}$. g) SEM on the vaginal pore. Bar $=50 \mu \mathrm{m}$. 
digital camera. The specimens studied have been deposited in the Helminthological Collection of the Oswaldo Cruz Institute (CHIOC no 37.526, 37527a-b, 37528) in Brazil.

A further ten samples of mature worms were prepared for SEM as follows. The specimens were firstly fixed for one hour at $4{ }^{\circ} \mathrm{C}$, in $2.5 \%$ glutaraldehyde in $0.1 \mathrm{M}$ sodium cacodylate buffer ( $\mathrm{pH} 7.2$ ), and were then washed in the same buffer three times for 15 minutes and post-fixed for one hour at room temperature with $1 \%$ osmium tetroxide in the same buffer. The specimens were then dehydrated in an ascending acetone series, dried by means of the critical point method with $\mathrm{CO}_{2}$, mounted with silver adhesive tape on aluminum stubs and coated with a layer of gold of thickness $60 \mathrm{~nm}$. The samples were examined under a Zeiss DSM 940 and a Jeol JSM-6390LV SEM, operated at $15 \mathrm{kV}$. The images were digitally captured onto an IBM-PC and processed using Adobe Photo Shop 7.0 software.

\section{Results}

The specimens of $G$. acanthura presented an elongated body that was constricted near the anterior extremity, with a haptor in the posterior portion as an extension of the body (Figure 1a and Figure 2e). Transverse striations and ridges, probably due to muscle contraction, were seen on the ventral body surface (Figures $1 \mathrm{~b}, \mathrm{c}$ ).

The buccal opening (mouth) is subterminal and ventral, at the anterior extremity of the body (Figures $1 \mathrm{~b}, \mathrm{c}$ ). The tegument around the buccal opening is wrinkled and elevated into folds, and it presented protuberances irregularly arranged extending for a short distance from the aperture (Figures 1b,c). Sensory papillae were also observed on the tegument around the buccal cavity (Figure 1c) and on the body surface, with apparently no defined distribution (Figures 1b,c).

The cirrus was observed to be everted from the genital atrium (Figures 1b,c) and armed with pectinate spines (Figures 1d,e). The genital atrium opens ventrally, posteriorly to the oral aperture and presents internal recurved pointed spines (Figures 1c,e). An eversible cirrus measuring $0.17 \mathrm{~mm}$ long $(0.16-0.2 \mathrm{~mm} ; \mathrm{n}=8)$ presented pectinate spines with up to eight tips along their length (Figures 1c-e). When the cirrus was completely everted, the base with its pointed spines was visible through the genital pore (Figure 1e).

The elongated haptor consists of 80 to $120(n=11)$ pedunculated clamps symmetrically distributed in one row on each side (Figures 2a,b) and presents a curved lappet at the posterior end with a pair of hooks at its tip (Figures $2 \mathrm{a}, \mathrm{b}$, inset). Each clamp is composed of two articulated jaws (Figures $2 \mathrm{c}, \mathrm{d}$ ) supported by a median sclerite (Figure 2c). Three to five rib-like thickenings are observed on the upper jaw of the clamp (Figures 2c,d). The clamps are coated with a wrinkled tegument, and the inner surface seemed to be smooth (Figure 2c).

Light microscopy and SEM observations showed that there was a well-developed muscular structure at the level of the constriction in the anterior region on the dorsal surface (Figures 2e,f), with tegument presenting wrinkles and a folded surface in a complex array (Figure 2g).

\section{Discussion}

Examination of the tegument of $G$. acanthura in the present study showed that the everted cirrus with pectinate spines and the muscular structure on the dorsal surface of the body elucidated the morphological features.

In their review of Gotocotylidae, Hayward and Rohde (1999) pointed out that the specimens studied using SEM that had been presented as $G$. bivaginalis (RAMALINGAM, 1961) by Ramasamy and Hanna (1989) actually belonged to $G$. acanthura. Considering that no slides are available, it is not possible to confirm this statement. As in the present study on $G$. acanthura, the specimens studied by Ramasamy and Hanna (1989) presented clamps with four to five prominent rib-like thickenings. In the opinion of Ramasamy and Hanna (1989), the likely function of the thickenings is to facilitate partial interlocking of adjacent clamps.

The function of the well-developed muscular structure on the dorsal surface of the body remains uncertain; some authors believed that it was an adhesive organ, while others considered that it was the vagina. Hayward and Rohde (1999) made serial transverse sections in this region and did not observe any internal duct. Nevertheless, they retained the term 'vagina' for the large muscular structure present in the anterior region of most members of this family We suggest that this structure may be an accessory sucker that has the purpose of holding the pair of worms on the gill surface during copulation.

These observations made on $G$. acanthura parasitizing Pomatomus saltatrix from the coast of the state of Rio de Janeiro suggest that the proposition of Hayward and Rohde (1999) can be accepted, since the surface topography of the specimens that Ramasamy and Hanna (1989) named G. bivaginalis is similar to that of Gotocotyla acanthura.

\section{Acknowledgements}

The authors are grateful to Anna Kohn, from the "Laboratório de Helmintos Parasitos de Peixes, Instituto Oswaldo Cruz, Brazil" for reading the manuscript and for the suggestions made, to Marielle Delfim Pereira from the "Laboratório de Biologia Estrutural, Instituto Oswaldo Cruz, Rio de Janeiro, Brasil” for technical assistance and to Dr. Luis Souhami from McGill Hospital, Montreal, Canada for reviewing the English of the manuscript.

\section{References}

BRAVO-HOLLIS, M.; CABALLERO-DELOYA, J. Catálogo de la Colección Helmintológica del Instituto de Biología. Anales de Instituto Biología de la Universidad Nacional Autónomique de México, Serie Zoología, v. 50, n. 1, p. 743-768, 1979.

HAYWARD, C. J.; ROHDE, K. Revision on the monogenean family Gotocotylidae (Polyopisthocotylea). Invertebrate Taxonomy, v. 13, n. 3 , p. 425-460, 1999. http://dx.doi.org/10.1071/IT98003

KOHN, A.; GOMES, D. C.; BÜHRNHEIM, U. Gotocotyla travassosi sp. n., gastrocotilideo de brânquias de enchova (Polistomata). Memórias do Instituto Oswaldo Cruz, v. 69, n. 1, p. 49-51, 1971. http://dx.doi.org/10.1590/S0074-02761971000100003 
KORATHA, K. J. Studies on the monogenetic trematodes of the Texas coast. II. Descriptions of species from marine fishes of Port Aransas. Publications of The Institute of Marine Science University of Texas, v. 4, n. 1, p. 251-278, 1955.

LEBEDEV, B. I. System of Monogenea of the Suborder Gastrocotylinea. In: MAMAEV, Y. L. et al. (Eds.). Parasites of Animals and Plants. Vladivostok: Akademiya Nauk SSR, 1984. p. 17-24.

LEBEDEV, B. I.; PARUKHIN, A. M. Monogenea of some fish from Wallfish Bay (South-Western Africa). Hydrobiologicheskij Zhurnal, v. 5, n. 6, p. 70-81, 1969.

RAMALINGAM, K. A redescription of Lithidiocotyle secunda Tripathi and its binomics. Journal of Madras University B, v. 31, p. 143-173, 1961.
RAMASAMY, P.; HANNA, R. E. B. The surface topography of Gotocotyla secunda and Gotocotyla bivaginalis (Monogenea, Polyopisthocotylea) from Scomberomorus commerson. International Journal for Parasitology, v. 19, n. 1, p. 63-69, 1989. http://dx.doi.org/10.1016/0020-7519(89)90022-2

SHEN, J. W.; QIU, Z. Z. Studies on the trematodes of fishes from the Yellow Sea and the Bo Hai Sea. Science Press: Beijing, 1995.

WILLLIAMS JUNOIR, E. H.; BUNKLEY-WILLIAMS, L. B. Parasites of offshore big game fishes of Puerto Rico and the Western Atlantic. Mayaguez: Puerto Rico Department of Natural and Environmental Resources and University of Puerto Rico, 1996. 382 p.

YOUNG, P. C. The species of Monogenoidea recorded from Australian fishes and notes on their zoogeography. Anales de Instituto Biología de la Universidad Nacional Autónomique de México, Serie Zoología, v. 41, n. 1, p. 163-176, 1970. 